\title{
CORROSION DAMAGE OF SEAM WELDED GALVANIZED HOT WATER PIPELINES
}

\author{
Dražen Živković, Nedjeljko Mišina, Petar Ljumović
}

Original scientific paper

The aim of this paper was to determine the cause of corrosion damage on hot water seam welded galvanized pipelines. Chemical analysis of the pipeline samples as well as their microstructure analysis has been undertaken. Visual inspection of samples of the internal surface of the pipelines was conducted, as well as the chemical analysis of water samples from specific regions of the hot water pipeline. The analysed samples came from the damaged pipeline, replaced pipeline and also from the new, unused pipelines and compared. The effects of the locally developing corrosion processes have been investigated. The influence of the welded joint structure and its heat-affected zone on the corrosion process intensity was analysed. The synergistic effect of zinc from the pipeline coating and the copper ions from the heat exchanger on the water systems corrosion development has been analysed. The fundamental preconditions of formation and development of various copper corrosion types were investigated, as well as the affecting influence of copper ions. The influence of hot water temperature against corrosion processes development was inspected. The testing results have showed that the corrosion process was generated due to the increase of copper concentration in hot water pipeline.

Keywords: copper corrosion; galvanized pipeline corrosion; hot water pipeline

\section{Korozijska oštećenja toplovodnih šavno zavarenih čeličnih pocinčanih cijevi}

Izvorni znanstveni članak

Svrha ovog rada bila je utvrditi uzrok nastajanja korozijskih oštećenja na toplovodnim čeličnim šavno zavarenim pocinčanim cijevima. U tu svrhu, bilo je potrebno provesti analizu kemijskog sastava cijevi toplovoda, ispitivanje mikrostrukture uzoraka cijevi, vizualni pregled unutarnjih površina cijevi te analizu kemijskog sastava uzoraka vode iz odabranih dijelova cjevovoda. Analizirani su uzorci cijevi oštećenog toplovoda, zamijenjenog toplovoda te novih nekorištenih cijevi. Istraživani su učinci lokaliziranih korozijskih procesa. Ispitivan je utjecaj strukture zavarenog spoja na intenzitet korozijskog procesa. Analiziran je sinergijski učinak cinka iz zaštitne prevlake cijevi i bakrenih iona iz izmjenjivača topline na razvoj korozijskih procesa unutar sustava toplovoda. Istraživane su temeljne pretpostavke za nastajanje i razvoj različitih oblika korozije bakra kao i utjecaj djelovanja bakrenih iona. Ispitan je utjecaj temperature vode u toplovodu na razvoj korozijskih procesa. Rezultati ispitivanja ukazuju da je korozijski proces nastao zbog povećane koncentracije bakra u cijevima toplovoda.

Ključne riječi: korozija bakra; korozija pocinčanog cjevovoda; toplovod

\section{Introduction}

In the last thirty years, a large number of professional and scientific studies regarding the influence of water dissolved copper ions on galvanized steel pipelines have been conducted. These studies were motivated by the intensive degradation of hot water pipelines, as well as the cold water ones, which were connected to different types of thermal aggregates (heaters, boilers, heat exchangers, etc.).

Development of new thermally more efficient aggregates, has led to a larger use of copper pipes.

The corrosion of copper (copper alloyed) pipes, consequently enriches the heat transfer media - water, with copper ions. With their precipitation on the pipes surfaces, galvanic cells are formed.

In this research, the analysis of the cause of damage forming on seam welded pipes for hot water was conducted. The hot water pipeline was located in a hotel complex. The research should address the following key points:

- Were the pipes in question made according to quality certificates, i.e. standards by which they were followed when imported to the Republic of Croatia and if they were not, did the extent of deviation in quality affect the progress of corrosion?

- What was the amount of copper; i.e. copper ions (in synergy with zinc) needed to induce corrosion and pipe deterioration?

- From where did the copper (copper ions) come into the hot water pipeline?
- Was the existence of copper ions in this case the main cause for corrosion and deterioration and why did similar deterioration type not occur in cold water pipeline system?

In this work, an additional surface condition analysis of damaged, replaced and new pipes from different manufacturers was conducted.

\section{$2 \quad$ Pipe testing \\ 2.1 Chemical analysis}

A chemical analysis of the base metal was conducted. Considering the fact that the pipe welding process was done without the addition of other material, the differences between the chemical composition of the base metal and welding joint was not expected. Test sample 1 was taken from the damaged pipeline from one manufacturer. Samples 2, 3 and 4 were taken from another manufacturer with sample 2 taken from the replaced pipeline. Samples 3 and 4 were taken from new pipes. Damaged pipes were in use for six months, while replaced pipes are still in exploitation.

The chemical composition analysis (shown in Tab. 1) suggested that the pipes were made from low-carbon construction steel graded as St 24, according to DIN $1614 / 2$ standard. Chemical composition comparison of the damaged, replaced and new pipeline samples showed difference in mass portion of carbon, silica and manganese.

However, the differences established in chemical composition had not significantly affected the low-carbon construction steel corrosion process. 
Table 1 Chemical composition of damaged, replaced and new pipeline samples

\begin{tabular}{|c|c|c|c|c|c|c|c|c|c|c|c|c|c|}
\hline \multicolumn{10}{|c|}{ Mass portion (\%) } \\
\hline Sample & $\mathrm{C}$ & $\mathrm{Si}$ & $\mathrm{Mn}$ & $\mathrm{P}$ & $\mathrm{S}$ & $\mathrm{Ni}$ & $\mathrm{Cr}$ & $\mathrm{Mo}$ & $\mathrm{Cu}$ & $\mathrm{Al}$ & $\mathrm{Ti}$ & $\mathrm{V}$ & $\mathrm{W}$ \\
\hline 1 & 0,05 & 0,003 & 0,265 & 0,008 & 0,008 & 0,009 & 0,007 & 0 & 0 & 0 & 0 & 0 & 0 \\
\hline 2 & 0,11 & 0,08 & 0,36 & 0,006 & 0,006 & 0,03 & 0,03 & 0 & 0,03 & 0,03 & 0,04 & 0 & 0 \\
\hline 3 & 0,08 & 0,05 & 0,21 & 0,003 & 0,015 & 0,03 & 0,04 & 0 & 0,05 & 0,03 & 0,01 & 0 & 0 \\
\hline 4 & 0,11 & 0,08 & 0,36 & 0,006 & 0,005 & 0,02 & 0,03 & 0 & 0,03 & 0,03 & 0 & 0 & 0 \\
\hline
\end{tabular}

\subsection{Microstructure analysis}

The microstructure analysis was conducted in a Laboratory for Metallographic Analysis within the Materials and Tribology Department at the Faculty of Electrical Engineering, Mechanical Engineering and Naval Architecture in Split (Croatia).

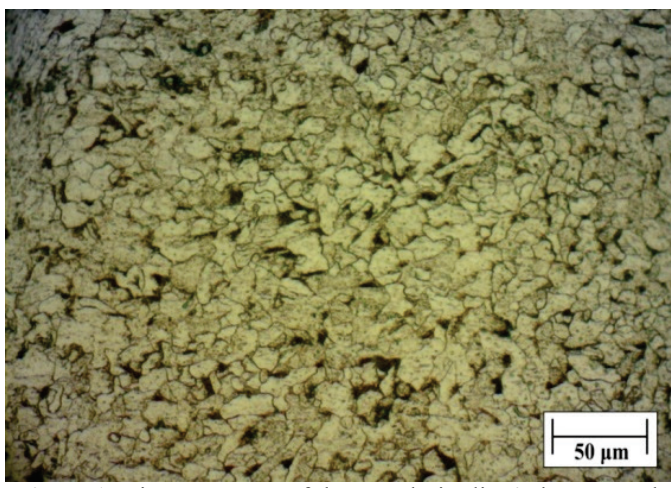

Figure1 Microstructure of damaged pipeline's base metal

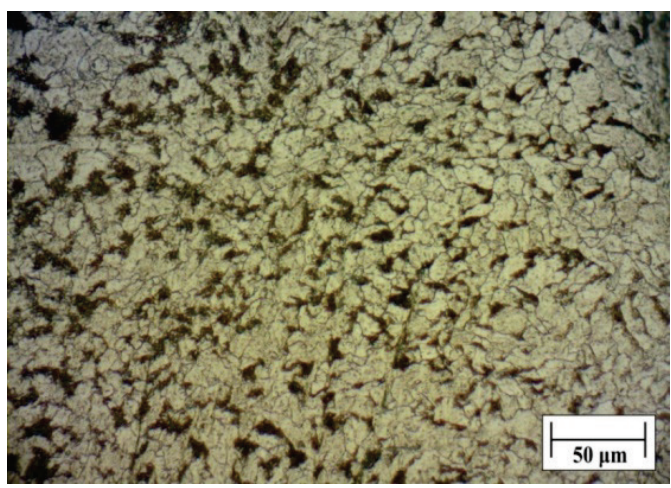

Figure 2 Microstructure of damaged pipeline's heat-affected zone

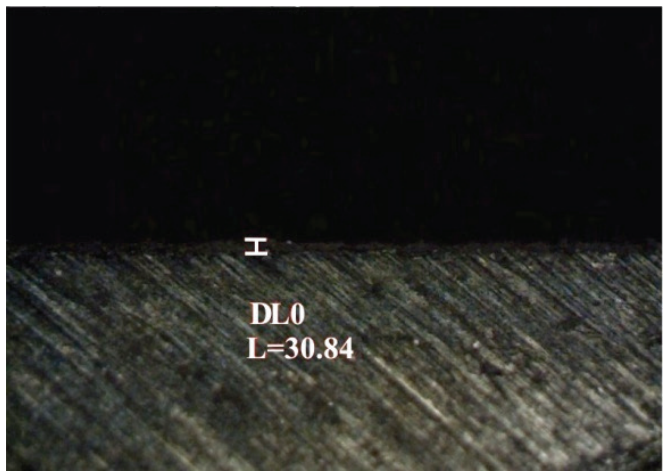

Figure3 Galvanized coating thickness of damaged pipeline's sample $(30,84 \mu \mathrm{m})$

Sample preparation for metallographic analysis was conducted by the use of cooling emulsion during the cutting process. The additional heat input during the cutting process was avoided by the use of the cooling emulsion. The samples were then ground and polished. NITAL (3\% nitrogen acid in ethyl alcohol solution) was used as a microstructure development agent. The microstructure analysis was conducted by an optical microscope, OPTON AXIOSKOP. For each sample, three metallographic images were generated regarding: base metal, heat-affected zone and galvanized coating thickness; Fig. $1 \div 6$.

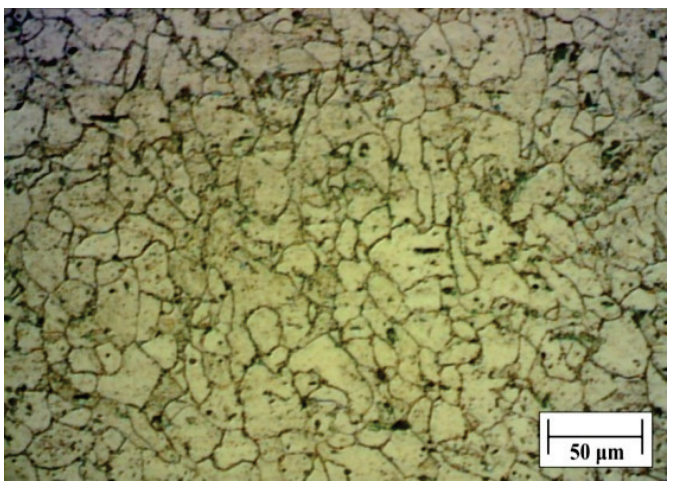

Figure4 Microstructure of new pipeline's base metal

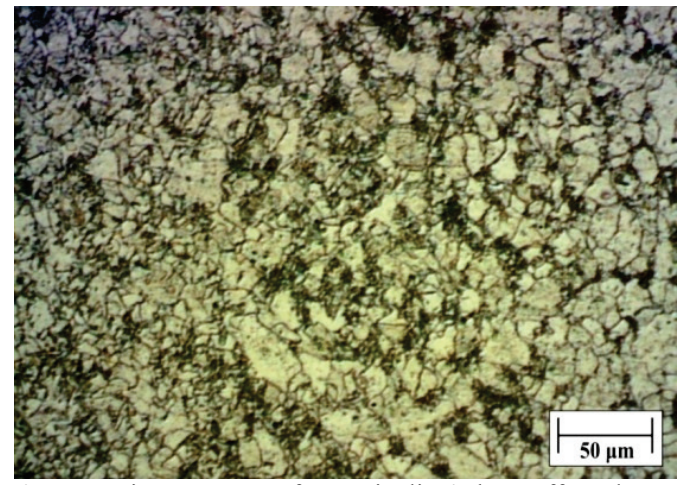

Figure5 Microstructure of new pipeline's heat-affected zone

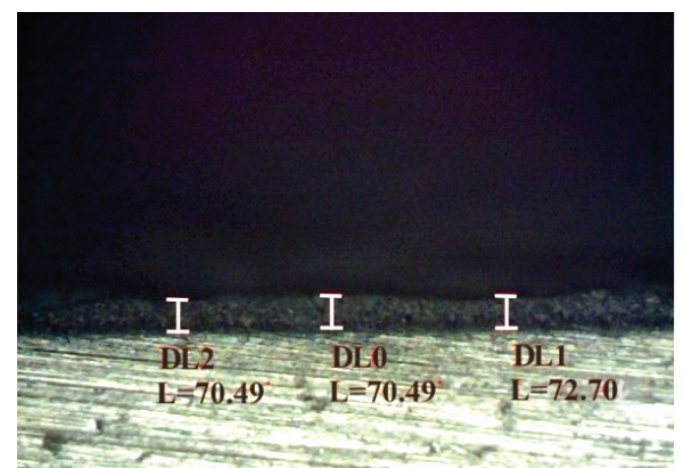

Figure6 Galvanized coating thickness of new pipeline's sample $(\sim 71 \mu \mathrm{m})$

Metallographic analysis of all tested samples showed:

- The structure of the base metal and the heat-affected zone was similar for both samples; i.e. there were no significant differences in size and shape of the crystal grains. The structure was ferritic-pearlitic;

- Differences in the galvanized coating thicknesses existed. For the damaged pipeline, the coating 
thickness was $30,84 \mu \mathrm{m}$ which could be a consequence of the galvanized coating wear due to the tested sample being exposed. Other galvanized coating thickness measurements (for new pipe samples) were inside within the proposed standards $(>55 \mu \mathrm{m})$.

\subsection{Visual inspection of pipelines inner surfaces}

Visual inspection was conducted on the pipeline segments of 25 to $75 \mathrm{~mm}$ in diameter. The inspection was focused on the base metal and the seam welded joint areas. Inspected pipes were from damaged, replaced and new pipeline sections; Fig. $7 \div 13$. The samples were taken from several places on the same pipe.

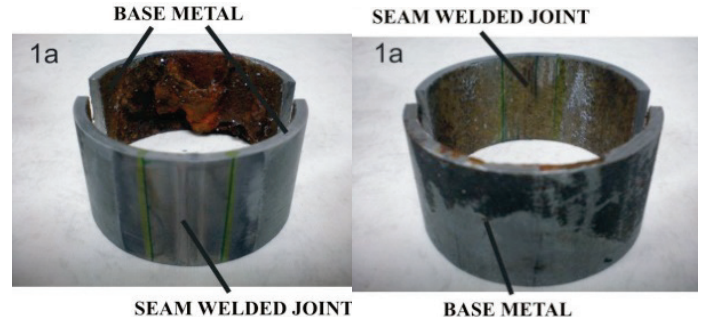

Figure 7 Damaged pipeline - base metal and seam welded joint; sample 1a

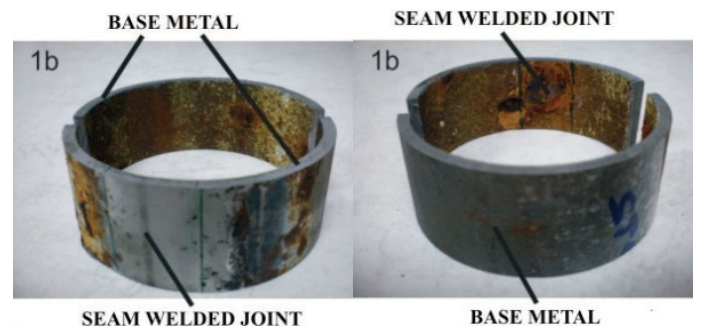

Figure 8 Damaged pipeline - base metal and seam welded joint; sample $1 \mathrm{~b}$

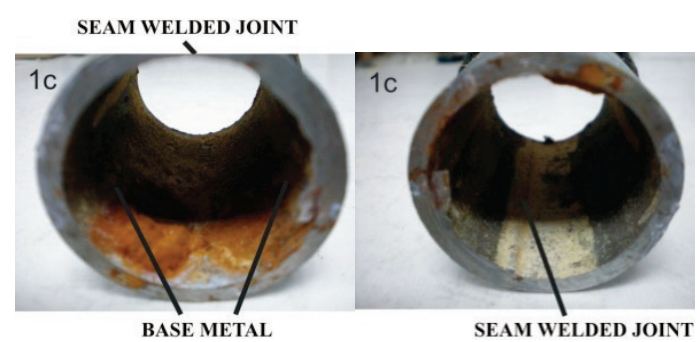

Figure 9 Damaged pipeline - base metal and seam welded joint samplelc

The visual inspection of all samples, except for the new ones (samples 3 and 4) showed that the corrosion process was in progress throughout all the inner surfaces of the pipes. Furthermore it was noted that on certain parts of the inner pipe walls, a significant cluster of corrosion products formed.

Based on the visual inspection, it was obvious that the corrosion process produced clusters. The copper ions were found in the clusters. The clusters were also found inside the pipes base metal, not only in the welded joint area. Moreover, an onward progression of the corrosion process was noted (Fig. $7 \div 12$ ).

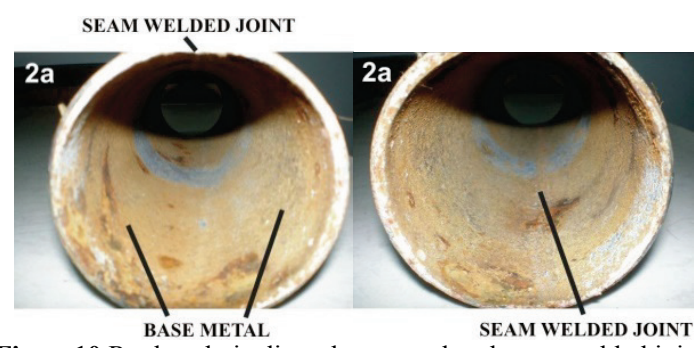

Figure10 Replaced pipeline - base metal and seam welded joint; sample $2 \mathrm{a}$

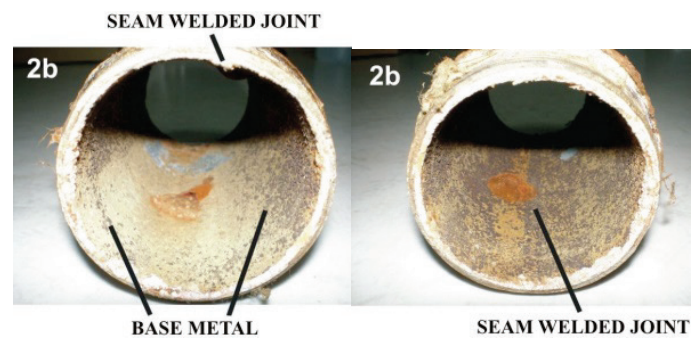

Figure11 Replaced pipeline - base metal and seam welded joint; sample $2 b$

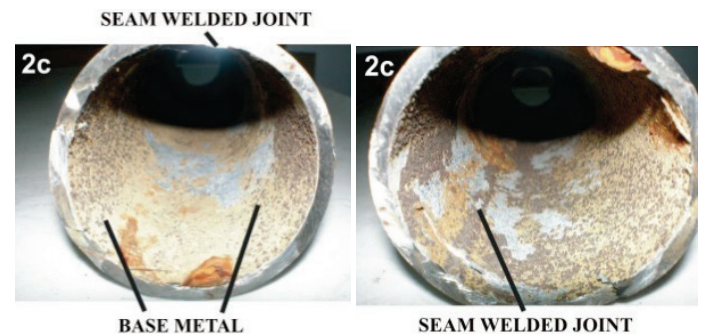

Figure12 Replaced pipeline - base metal and seam welded joint; sample 2c

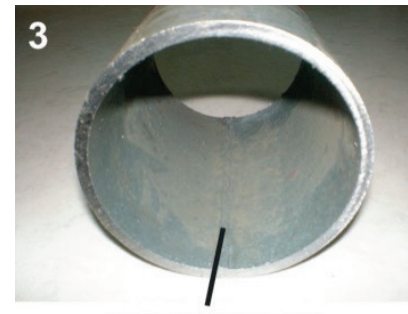

SEAM WELDED JOINT

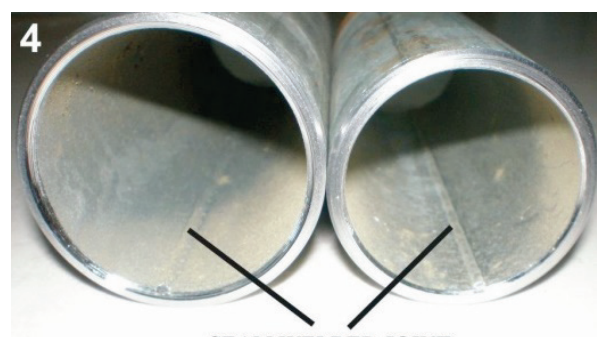

SEAM WELDED JOINT

Figure 13 New pipeline - base metal and seam welded joint; samples 3 and 4

\subsection{Chemical analysis of water samples}

For research purposes, two samples of hot water were taken and stored in 0,5 1 clean plastic bottles. The water samples were taken from a tap located in a boiler-room and a tap located in one hotel room. Considering the research plan and particular influence of the copper ions in hot water, chemical composition analysis was reduced to determine the copper ions content in previously 
mentioned water samples. Testing results are given in Tab. 2.

Table 2 Copper content in water samples

\begin{tabular}{|l|c|c|}
\hline Water sample & Sample tag & $\mathrm{Cu}(\mu \mathrm{g} / \mathrm{l})$ \\
\hline Hotel room & $2064 / 14 \mathrm{k}$ & 47,87 \\
\hline Boiler - room & $2065 / 14 \mathrm{k}$ & 52,28 \\
\hline
\end{tabular}

The analysis of water samples was conducted at the Teaching Institute for Public Health, Split - Dalmatia County; Division of Environmental Health in Split.

The analysis was conducted according to HRN EN ISO 15586: 2008 standard.

Based on previous chemical composition analysis results of the water used in the hot water pipeline during the time when the damage occurred, the following can be concluded:

- $\mathrm{pH}$ values were in the interval from 7,137 (recirculation water) to 7,941 (boiler water);

- TDS (dissolved solid substance amount) was in the interval from $259 \mathrm{mg} / 1$ (boiler water) to $291 \mathrm{mg} / 1$ (recirculation water);

- Copper content was in the interval from 143,6 $\mu \mathrm{g} / 1$ (boiler water) to $145,9 \mu \mathrm{g} / 1$ (recirculation water);

- Iron content was in the interval from $166 \mu \mathrm{g} / \mathrm{l}$ (boiler water) to $10310 \mu \mathrm{g} / 1$ (recirculation water);

- $\quad$ Zinc content was in the interval from $566 \mu \mathrm{g} / \mathrm{l}$ (boiler water) to $3508 \mu \mathrm{g} / \mathrm{l}$ (recirculation water);

- Copper content in hydrant water was 4,2 $\mu \mathrm{g} / 1$.

The increased content of iron and copper ions from the boiler water, as well as from the recirculation water indicated that a corrosion process occured inside the pipeline system.

By comparison of the water analysis results from the period when damage occurred and the results shown in Tab. 2, a significant difference in the copper ions content was found. The water samples taken from the period when damage occurred (previous research), contained three times the amount of copper ions $(143,6 \mu \mathrm{g} / 1,145,9$ $\mu \mathrm{g} / \mathrm{l})$ than the samples presented in Tab. 2 .

\section{Discussion}

The discontinuities determined in geometry of the inner part of the seam welded joint (blow-through, droplet formation) do not have influence on the corrosion process occuring. Corrosion processes are developing locally, creating a tribological wear mechanism called "tribocorrosion". Corrosion processes, similar to the ones found in discontinuities of seam welded joint's geometry, are also found in the base metal areas. Discontinuities can induce a slight increase of corrosion process intensity in comparison to the corrosion process intensity in the base metal. These phenomena are common in cases when the conditions for galvanic corrosion development inside galvanized pipelines are created.

Welded joints are places where the material structure is considerably changed during a welding process. Different cooling rates of welded joints generate a different type of grains formation regarding their shape and size. This inhomogeneous structure, commonly tensed by inner stress, reacts much more turbulently in cases of galvanic cell formation. The characteristics of these spots is extremely anodic in comparison to the remaining pipe material. The welded joint structure influencing the intensity of the corrosion process is a commonly known reference and already discussed in the literature $[1,2]$.

A synergistic influence of copper and zinc is given as an important element of the corrosion process intensity increase. This fact is more significant in hot water pipelines with water temperatures exceeding $60{ }^{\circ} \mathrm{C}$. In these conditions, zinc, normally of anodic character, changes its potential and becomes cathodic like copper. Consequently, zinc ions do not protect the base metal (low-carbon steel) any more [3,4]. The copper ions came from a heat exchanger into the zinc-protected steel hot water pipeline system. Heat exchangers are the constituting parts of a hot water preparation and distribution facility. Moreover, the heat exchangers are made of copper pipe bundles; i.e. pipes are made of copper alloys.

Copper pipe corrosion subsequently enriches the heat transfer media - water, with copper ions that eventually form galvanic cells by precipitating on surfaces of galvanized pipelines. Literature data conclude that conditions for galvanic corrosion development already start at $100 \mu \mathrm{g} / \mathrm{l}$ of the copper concentration. Due to the increase of the copper content, the corrosion process steps up even more $[2,5]$.

Copper corrosion appears in several forms such as: cuprosolvency or general corrosion, cold water pitting, hot water pitting, erosion-corrosion and concentration cell-corrosion $[6,7]$.

In hot water pipelines a common form of copper corrosion is hot water pitting, developing as a consequence of a micro precipitation of the cathodic materials such as: manganese-dioxide, aluminiumhydroxide and hydrated hematite. In that case, the dissolution of copper's coating layer occurs. Copper reacts with oxygen and forms thin oxide layers on its surface $\left(\mathrm{Cu}_{2} \mathrm{O}\right.$ and $\left.\mathrm{CuO}\right)$ that considerably decrease the corrosion's progress rate. Development of this particular corrosion type is assisted by increased water temperature. Several researches accentuated the water temperature issues in pipelines. In water containing manganese, and heated to $60{ }^{\circ} \mathrm{C}$ or more, the possibility for indissoluble manganese dioxide $\left(\mathrm{MnO}_{2}\right)$ forming emerges, which works as a strong cathodic depolarizer thus supporting a copper corrosion process [7].

According to literature data, the durability of copper alloys in aquatic environments with no conditions present for developing intensive copper corrosion process, exceeds 50 years (dependable on copper pipe wall thickness) [8].

Due to the obtained chemical composition results suggesting the existence of increased amount of manganese $(1115 \mu \mathrm{g} / \mathrm{l})$ and by taking into account that the water temperature was below the critical value of $60^{\circ} \mathrm{C}$, it can be concluded that a possibility of this type of corrosion development occured.

An increased concentration of copper ions in hot sanitary water is a fundamental cause for corrosion developing on the inner surfaces of the galvanized pipeline. A significant number of references as well as the 
standards from various societies engaged in water installations business (Foundation for Water Research, UK; United States Environmental Protection Agency, US, Water Engineering Research Laboratory, US; American Water Works Association, US; University of Science and Technology - Krakow, Poland; etc.), are dealing with issues regarding the connection of copper-based thermal aggregates and zinc-protected steel pipelines. Literature data point to a few important influencing elements on galvanized pipeline corrosion processes. The presence of copper ions in water is primary emphasised, followed by the condition of galvanized pipeline inner surfaces. The type of base metal and/or the composition and quality of zinc coatings is noted, along with the temperature and flow rate of sanitary water [4, 5, 6, and 8].

The corrosion process takes place when copper ions, dissolve in sanitary water and precipitate on the galvanized steel pipes surfaces. Therefore the copper ions are in direct contact with the zinc's coating layer. Since there is no considerable difference in electro potentials of copper and zinc, galvanic cell phenomenon occurs. Copper (electro positive) is more of a noble metal than zinc (electro negative), therefore it represents a cathode in a galvanic cell. Zinc, in this case is anodic in character, and wears away intensively. The zinc coating layer on the surface of low-carbon steel pipes locally wears off and generates pitting. When the coating layer is locally removed, the corrosion process progresses on to the steel surface and advances all the way, perforating the pipe walls. Some authors are introducing a case of an increased sanitary water temperature $\left(60^{\circ} \mathrm{C}\right)$, where a local anode cathode interaction changes; i.e. zinc that represented a sacrificial anode up to that particular point, becomes cathodic in character, while a steel surface becomes anodic. This phenomenon increases a local corrosion process even more. In the literature, some references with a particular regard to this matter were found. They suggest that this type of corrosion is mostly found in central heating and cooling systems of business facilities, hotels, hospitals etc., i.e. in sanitary water heating systems with copper-based heat exchangers built-in [3].

In cases that for any reason whatsoever project engineers are not in a position to avoid connection of the aggregates with copper elements and galvanized steel pipelines, it is necessary to protect the pipeline from copper ions getting inside. A protection can be conducted by installing a special scavenger pot between aggregate heating system and galvanized steel pipeline. Metals of a higher position on the galvanic scale than copper are present in scavenger pots and bind with free copper ions from heated sanitary water. These metals commonly are mossy zinc and magnesium. Thus, copper ions are successfully prevented from entering the water supply pipeline [3]. Cold water from a sanitary water pipeline does not run through the heat exchanger system and therefore it does not get enriched with copper ions. The concentration of copper ions in cold water is similar to the concentration of the ones found in hydrant water sample $(4,2 \mu \mathrm{g} / \mathrm{l})$, which happens to be considerably lower than the copper concentration's critical value $(100 \mu \mathrm{g} / \mathrm{l})$ for the galvanic corrosion to begin.
This is a fundamental reason why the intensive corrosion process does not occur on surfaces of the cold water pipelines.

\section{Conclusion}

A fundamental cause for premature damage of analysed sanitary water pipeline was a corrosion process developing on protective zinc-coating of low-carbon steel pipes.

The corrosion process usually develops by galvanic cells formation between copper ions (dissolved in hot sanitary water and precipitating on extracted pipeline areas), and protective zinc coatings.

In our research case study, if the reached copper concentration (in water) was considerably lower than critical, a corrosion process generated through galvanic cell forming would be stoped or would be of a considerably lower intensity. Furthermore, if the pipeline's water temperature was lower than critical $(<60$ ${ }^{\circ} \mathrm{C}$ ), the corrosion process would be much slower.

Due to the imperfection of certain parts of seam welded joint's geometry, at already formed copper ion precipitations in those places, more rapid corrosion development is expected.

The imperfections of seam welded joints were not the reason for corrosion process development on inner walls of zinc-protected steel pipeline. Corrosion also occurred on the pipeline's base metal.

The results of the chemical composition analysis have showed that new and damaged pipes were of similar chemical content. The structure of new and damaged pipes was identical. It is important to emphasize that after the damaged pipes had been replaced, the intensive corrosion process did not occur. A probable cause for this was lower copper ions concentration in the water samples taken $(52,28 \mu \mathrm{g} / \mathrm{l})$, which was almost two times lower than the critical concentration for galvanic corrosion (100 $\mu \mathrm{g} / \mathrm{l})$. Also, a measured sanitary water's temperature of 54 ${ }^{\circ} \mathrm{C}$, was below the critical value of $60^{\circ} \mathrm{C}$.

\section{Acknowledgments}

Authors express special thanks to Ph.D. David Kennedy for his help with proofreading of the English translation.

\section{References}

[1] Internal Corrosion, Second edition, American Water Works Association Research Foundation, AWWA, ISBN 089887759-9, 1996

[2] The Premature Deterioration of Zinc-coated Steel Pipes in Water Distribution System, GH University of Science and Technology, Krakow, Poland, 2013.

[3] Corrosion Manual for Internal Corrosion of Water Distribution Systems, Environmental Protection Agency, EPA 570/9-84-001, US, 1984.

[4] Copper-Induced Corrosion of Galvanized Steel Pipe, Environmental Protection Agency, EPA 600/S2-86/056, US, 1986.

[5] Cruse, H. Disolved-Copper Effect on Iron Pipe. // Journal American Water Works Association. 63, 2(1971), pp. 7981. 
[6] Cohen, A. Corrosion by Potable Waters in Building Systems. // Materials Performance. 32, (1993), pp. 56-61.

[7] Oliphant, R. J. Causes of Copper Corrosion in Plumbing Systems, Foundation for Water Research, UK, 2010.

[8] White, R. T.; Pressly, J. T.; O’Donnel, A. J. A guide to performance of hot dip galvanized piping in Water, South Africa Bureau of Standards, Pretoria, 2002.

\section{Authors' addresses}

Dražen Živković, prof. dr. sc.

University of Split

Faculty of Electrical Engineering, Mechanical Engineering and

Naval Architecture

Ruđera Boškovića 32

21000 Split, Croatia (EU)

E-mail: Drazen.Zivkovic@fesb.hr

Nedjeljko Mišina, prof. dr. sc.

University of Split

Faculty of Electrical Engineering, Mechanical Engineering and

Naval Architecture

Ruđera Boškovića 32

21000 Split, Croatia (EU)

E-mail: nmisina@fesb.hr

Petar Ljumović, struč. spec. ing. mech.

University of Split

Faculty of Electrical Engineering, Mechanical Engineering and

Naval Architecture

Ruđera Boškovića 32

21000 Split, Croatia (EU)

E-mail: petarlj@fesb.hr 